\title{
DEVELOPMENT AND VALIDATION OF DIFFERENTIAL PULSE POLAROGRAPHIC ANALYSIS OF FENOFIBRATE IN PURE AND PHARMACEUTICAL DOSAGE FORMS USING DROPPING MERCURY ELECTRODE
}

\author{
ABDUL AZIZ RAMADAN ${ }^{*}$, HASNA MANDIL², REHAM ABU-SALEH \\ Department of Chemistry, Faculty of Science, University of Aleppo, Syria \\ Email: dramadan@scs-net.org, mandil@scs-net.org
}

Received: 11 May 2016 Revised and Accepted: 01 Sep 2016

\section{ABSTRACT}

Objective: An easy, fast, accurate and sensitive differential pulse polarographic analysis for determination of fenofibrate (FEN) in pure and pharmaceutical dosage forms using dropping mercury electrode (DME) was applied.

Methods: The method involves the electrochemical reduction of fenofibrate at DME by differential pulse polarographic analysis (DPPA). Different buffer solutions were used over a wide $\mathrm{pH}$ range (1.0-10.0). The best definition of the analytical signals was found in lithium perchlorate trihydrate buffer at $\mathrm{pH} 6.0$ containing $24 \%(\mathrm{v} / \mathrm{v}$ ) acetonitrile at-994 to- $1025 \mathrm{mV}$ (versus $\mathrm{Ag} / \mathrm{AgCl})$.

Results: Under optimized conditions the peak current $\left(\mathrm{I}_{\mathrm{p}}\right)$ is linear over the range 0.0361-3.608 $\mu \mathrm{g} / \mathrm{ml}$. The DPPA was used successfully for the determination of FEN in pure and pharmaceutical dosage forms. The relative standard deviation did not exceed $2.1 \%$ for the concentration of FEN $0.0361 \mu \mathrm{g} / \mathrm{ml}$. Regression analysis showed a good correlation coefficient $\left(\mathrm{R}^{2}=0.9994\right)$ between Ip and concentration at the mentioned range. The limit of detection (LOD) and the limit of quantification (LOQ) was to be 0.0025 and $0.0076 \mu \mathrm{g} / \mathrm{ml}$, respectively. The proposed method was validated for linearity, precision and accuracy, repeatability, sensitivity (LOD and LOQ), robustness and specificity with an average recovery of 99.8-100.6\%.

Conclusion: The developed method is applicable for the determination of FEN in pure and different dosage forms with the assay of marketed formulations 99.8-104.0\% and the results are in good agreement with those obtained by square-wave voltammetry (SWV) reference method.

Keywords: Differential pulse polarographic analysis, Fenofibrate, Pharmaceutical formulations

(C) 2016 The Authors. Published by Innovare Academic Sciences Pvt Ltd. This is an open access article under the CC BY license (http://creativecommons.org/licenses/by/4. 0/) DOI: http://dx.doi.org/10.22159/ijpps.2016v8i10.12762

\section{INTRODUCTION}

Fenofibrate (FEN) a third-generation fibric acid derivative, is a highly effective agent for the treatment of atherogenic dyslipidemias. FEN therapy also produces substantial reductions in the levels of very-low-density lipoprotein cholesterol (VLDL-C) and in the concentration of triglyceride-rich lipoproteins. FEN is a prodrug which is hydrolyzed by tissue and plasma esterases to the active metabolite fenofibrate acid [1, 2]. FEN is slightly soluble in acetonitrile and ethanol (95\%), very soluble in methylene chloride and insoluble in water. The molecular formula of FEN is $\mathrm{C}_{20} \mathrm{H}_{21} \mathrm{Cl}_{5} \mathrm{O}_{4}$ and the molecular weight is $360.831 \mathrm{~g} / \mathrm{mol}$, see Scheme 1 .

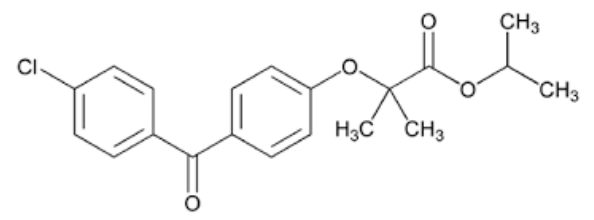

Scheme 1: Chemical structure of Fenofibrate (FEN)

The electrochemical reduction of FEN at a hanging mercury drop electrode (HMDE) was investigated by cyclic voltammetry (CV), square wave voltammetry (SWV) and chronoamperometry. Different buffer solutions were used over a wide $\mathrm{pH}$ range $3.0-$ 10.0). The best definition of the analytical signals was found in borate buffer (pH 9.0) tetrabutylammonium iodide mixture containing $12.5 \%(\mathrm{v} / \mathrm{v})$ methanol at $-1.2 \mathrm{~V}$ (versus $\mathrm{Ag} / \mathrm{AgCl}$ ). According to CV studies, the reduction was irreversible and diffusion controlled.
Validation parameters such as sensitivity, accuracy, precision and recovery were evaluated. The proposed method was applied to the determination of fenofibrate in pharmaceutical formulations [3]. The results were compared with those obtained by a published highperformance liquid chromatography method [4]. No difference was found statistically. Fenofibrate was determined in their pharmaceutical preparations and human plasma using differential pulse polarographic (DPP) and SWV techniques by reduction at a dropping mercury working electrode (DME) versus $\mathrm{Ag} / \mathrm{AgCl}$ reference electrode. Optimum conditions such as $\mathrm{pH}$, scan rate, and pulse amplitude were studied, and validation of the proposed method was performed. The proposed methods proved to be accurate, precise, robust and specific for determination of the drug [5]. Several analytical methods for the determination of fenofibrate have been reported including high-performance liquid chromatography (HPLC) $[3,6-8]$ and spectrophotometric methods [9-11].

In the present work, development and validation of differential pulse polarographic determination of fenofibrate in pure and pharmaceutical dosage forms using dropping mercury electrode was applied. The method is easy, fast, accurate and sensitive for the determination of this compound in pharmaceutical formulations.

\section{MATERIALS AND METHODS}

Reagents and instruments

Working reference standard of fenofibrate (99.5\%) was supplied by D. K. Pharmachem Pvt. Ltd (INDIA), (Mfg. 12-2014, Exp. 11-2019). Lithium perchlorate trihydrate, di-Sodium tetraborate decahydrate (borax), disodium hydrogen phosphate dodecahydrate, sodium acetate trihydrate, sodium hydroxid, perchloric acid $70 \%$, orthophosphoric acid (85\%), methanol, ethanol (absolute) and acetonitrile were of GR for analysis purchased from MERCK. 
A Metrohm 746 VA processor, A Metrohm 747 VA stand with a dropping mercury electrode (DME) as a working electrode, a platinum auxiliary electrode and a reference electrode, double junction type, $(\mathrm{Ag} / \mathrm{AgCl})$ saturated with a $3.0 \mathrm{M} \mathrm{KCl}$ solution and the three-electrode cell were used. All measurements were done at room temperature $25 \pm 5{ }^{\circ} \mathrm{C}$. Highly pure nitrogen gas (99.999\%) was used for de-oxygenation. $\mathrm{pH}$ meter from Radiometer company model ion check was used for the studying and monitoring the $\mathrm{pH}$ effects. The diluted pipette model DIP-1 (Shimadzu), having $100 \mu \mathrm{L}$ sample syringe and five continuously adjustable pipettes covering a volume range from 20 to $5000 \mu \mathrm{L}$ (model PIPTMAN P, GILSON), were used for the preparation of the experimental solutions. An ultrasonic processor model Power sonic 405 was used to sonicate the sample solutions. Electronic balance (Sartorius-2474; $d=0.01$ $\mathrm{mg}$ ) was used for weighing the samples.

\section{Supporting electrolyte}

Lithium perchlorate trihydrate buffer $1.000 \mathrm{~mol} / \mathrm{l}$ (16.044 g/100 $\mathrm{ml})$ at $\mathrm{pH} 6.0$.

\section{A standard stock solution of fenofibrate $\left(1 \times 10^{-4} \mathrm{~mol} / \mathrm{l}\right)$}

This solution was prepared by dissolving $18.13 \mathrm{mg}$ from fenofibrate in $50 \mathrm{ml}$ acetonitrile $\left(1 \times 10^{-3} \mathrm{~mol} / \mathrm{l}\right)$, then diluting $10.000 \mathrm{ml}$ from this solution to $100 \mathrm{ml}\left(1 \times 10^{-4} \mathrm{~mol} / \mathrm{l}\right)$.

\section{Working solutions}

The stock solutions were further diluted to obtain working solutions daily just before use in the concentrations of FEN: 0.100, 0.200, $0.400,0.600,0.800,1.000,2.000,4.000,6.000,8.000$ and 10.000 $\mu \mathrm{mol} / \mathrm{l}(0.0361,0.0722,0.1443,0.2165,0.2887,0.3608,0.7217$, $1.4433,2.165,2.887$ and $3.608 \mu \mathrm{g} / \mathrm{ml}$ ) by dilution of the volumes: $0.025,0.050,0.100,0.150,0.200,0.250,0.500,1.000,1.500,2.000$ and $2.500 \mathrm{ml}$ from stock standard solutions which were transferred into a $25 \mathrm{ml}$ volumetric flasks. $6.0 \mathrm{ml}$ of acetonitrile and $1.0 \mathrm{ml}$ of supporting electrolyte were added and diluted with double distilled deionized water to the mark. Ultrapure mercury from Metrohm Company was used throughout the experiments.

\section{Sample preparation}

A commercial formulations (as capsules) were used for the analysis of FEN by using DPPA with DME) the pharmaceutical formulations were subjected to the analytical procedures:

(1) Lipa capsule, Medical Bahri Co., Damascus-SYRIA, each capsule contains $100 \mathrm{mg}$ of FEN (Exp. 12.2018).

(2) Lipa capsule, Medical Bahri Co., Damascus-SYRIA, each capsule contains $300 \mathrm{mg}$ of FEN (Exp. 08.2019).

(3) Lipozor capsule, Avenzor, Damascus-SYRIA, Each capsule contains $250 \mathrm{mg}$ of FEN (Exp. 08.2017).

\section{Stock solutions of pharmaceutical formulations}

Contents of 20 capsules of each studied pharmaceutical formulation were weighed accurately, crushed to a fine powder and mixed well. An amount equivalent to $25 \%$ from the weight of one capsule content, was solved in $20 \mathrm{ml}$ acetonitrile by using ultrasonic, filtered over a $25 \mathrm{ml}$ flask and diluted to $25 \mathrm{ml}$ with acetonitrile, the resulting solution contains the follows: 1000,2500 and $3000 \mu \mathrm{g} / \mathrm{ml}$ for all studied pharmaceutical formulations content 100,250 and $300 \mathrm{mg} / \mathrm{cap}$, respectively.

\section{Working solutions of pharmaceuticals}

These solutions were prepared daily by diluting $200 \mu \mathrm{l}$ from stock solutions of each pharmaceutical formulations, adding $8.00 \mathrm{ml}$ from supporting electrolyte and $48 \mathrm{ml}$ acetonitrile, then diluting to $200 \mathrm{ml}$ with double distilled deionized water, these solutions contain 1.000, 2.500 and $3.000 \mu \mathrm{g} / \mathrm{ml}$ of FEN, respectively.

\section{Analytical procedure}

$25 \mathrm{ml}$ of working solutions of fenofibrate or working solutions of pharmaceuticals was transferred to the cell. The solution was deoxygenated with $\mathrm{N}_{2}$ gas for $300 \mathrm{~s}$. The studied potential range was from-650 to- $1400 \mathrm{mV}$ versus $\mathrm{Ag} / \mathrm{AgCl}$ with differential pulse polarographic analysis using dropping mercury electrode in the optimum conditions were applied.

\section{RESULTS AND DISCUSSION}

\section{Differential pulse polarographic behavior}

The polarograms for concentration 0.10-10.0 $\mu \mathrm{mol} / \mathrm{l}$ (0.0361-3.608 $\mu \mathrm{g} / \mathrm{ml}$ ) of FEN in the optimal conditions (supporting electrolytes, $\mathrm{pH}$, an organic solvent, scan rate, initial potential, final potential.... etc.) using DPPA at DME were studied. The best definition of the analytical signals was found in lithium perchlorate trihydrate $(0.04 \mathrm{M})$ buffer at $\mathrm{pH} 6.0$ containing $24 \%(\mathrm{v} / \mathrm{v}$ ) acetonitrile at-994 to- $1025 \mathrm{mV}$ (versus $\mathrm{Ag} / \mathrm{AgCl}$ ).

\section{The effect of supporting electrolytes (buffer)}

Different buffer solutions (lithium perchlorate trihydrate, sodium acetate trihydrate, disodium hydrogen phosphate dodecahydrate, disodium tetraborate decahydrate) containing $24 \%$ (v/v) acetonitrile were used. The best definition of the analytical signals was found in lithium perchlorate trihydrate buffer ( $\mathrm{pH}$ 6.0). The effect of supporting electrolytes (buffer) on the peak current $\left(\mathrm{I}_{\mathrm{p}}\right)$ and $\mathrm{E}_{\mathrm{p}}$ was studied. It was found that the lithium perchlorate trihydrate was the best buffer at concentration $0.04 \mathrm{~mol} / \mathrm{l}$. The values of $\mathrm{E}_{\mathrm{p}}$ were 1001, 1097, 1124 and $1132 \mathrm{mV}$ for the mention buffers, respectively, see fig. 1.

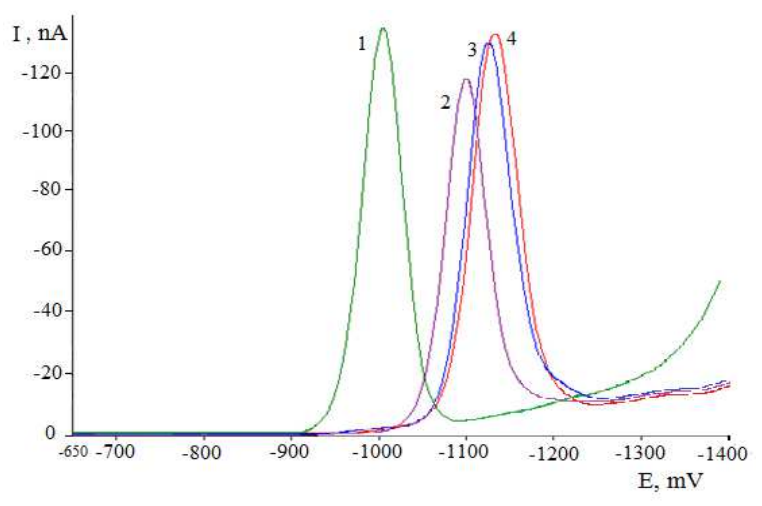

Fig. 1: The effect of buffer solutions on polarograms of FEN $(2.800$ $\mu \mathrm{M})$ using DPPA at DME containing $24 \%(\mathrm{v} / \mathrm{v})$ acetonitrile with (0.04 M) buffers: 1- $\mathrm{LiClO}_{4} .3 \mathrm{H}_{2} \mathrm{O}, 2-\mathrm{NaCH}_{3} \mathrm{COO} .3 \mathrm{H}_{2} \mathrm{O}, 3-$

$\mathrm{Na}_{2} \mathrm{HPO}_{4.12} \mathrm{H}_{2} \mathrm{O}, 4-\mathrm{Na}_{2} \mathrm{~B}_{4} \mathrm{O}_{7} .10 \mathrm{H}_{2} \mathrm{O}$ (Purge gas $\mathrm{N}_{2}$, purge time 300 $\mathrm{s}$, sweep rate $5 \mathrm{mV} / \mathrm{s}$, U. amplitude- $60 \mathrm{mV}$, t. meas. $32 \mathrm{~ms}$, t. pulse $45 \mathrm{~ms}$, t. step $1.6 \mathrm{~s}$, U. step $8 \mathrm{mV}$, temperature $25^{\circ} \pm 5^{\circ} \mathrm{C}$ )

\section{The effect of $\mathrm{pH}$}

The influence of $\mathrm{pH}$ from 1.0 to 10.0 using different buffer solutions on $\mathrm{I}_{\mathrm{p}}$ and $E_{p}$ was studied. The best definition of the analytical signals was found in lithium perchlorate trihydrate $(0.04 \mathrm{M})$ buffer $(\mathrm{pH} 6.0)$ containing $24 \%(\mathrm{v} / \mathrm{v})$ acetonitrile. The values of $\mathrm{I}_{\mathrm{p}}$ increase with increasing $\mathrm{pH}$ value of 1.0 to 5.0 , then become semi-fixed until $\mathrm{pH} 6.5$, and finally decrease until $\mathrm{pH} 10.0$. A pH value of 6.0 was optimal for FEN as the peak current $\left(\mathrm{I}_{\mathrm{p}}\right)$ was the highest at this $\mathrm{pH}$ value. While $\mathrm{E}_{\mathrm{p}}$ values are growing a negative value from- $862 \mathrm{mV}$ (when $\mathrm{pH} 1.0$ ) to- $986 \mathrm{mV}$ (when pH 5.0), then become semi-fixed until pH 10.0, see fig. (2).

\section{The effect of organic solvent}

The effect of some organic solvents (methanol, ethanol and acetonitrile) on $\mathrm{I}_{\mathrm{p}}$ showed that, $\mathrm{I}_{\mathrm{p}}$ increases with increasing ratio of organic solvents until a specific value (methanol $40 \%$, ethanol $28 \%$ and acetonitrile $24 \%, v / v)$ and then decreases, while $E_{p}$ almost did not change, see fig. (3and4).

\section{The effect of negative pulse amplitude ( $\mathrm{U}$ ampl.)}

The effect of negative pulse amplitude (U ampl.) between-10 to-100 $\mathrm{mV}$ on $\mathrm{I}_{\mathrm{p}}$ and Ep was studied. $\mathrm{I}_{\mathrm{p}}$ linearly increases with increasing amplitude value until- $60 \mathrm{mV}$ and then increases slowly, while $\mathrm{E}_{\mathrm{p}}$ has a positive value increasing. The value- $60 \mathrm{mV}$ was better than another's (the peak was in the best shape), see fig. (5). 

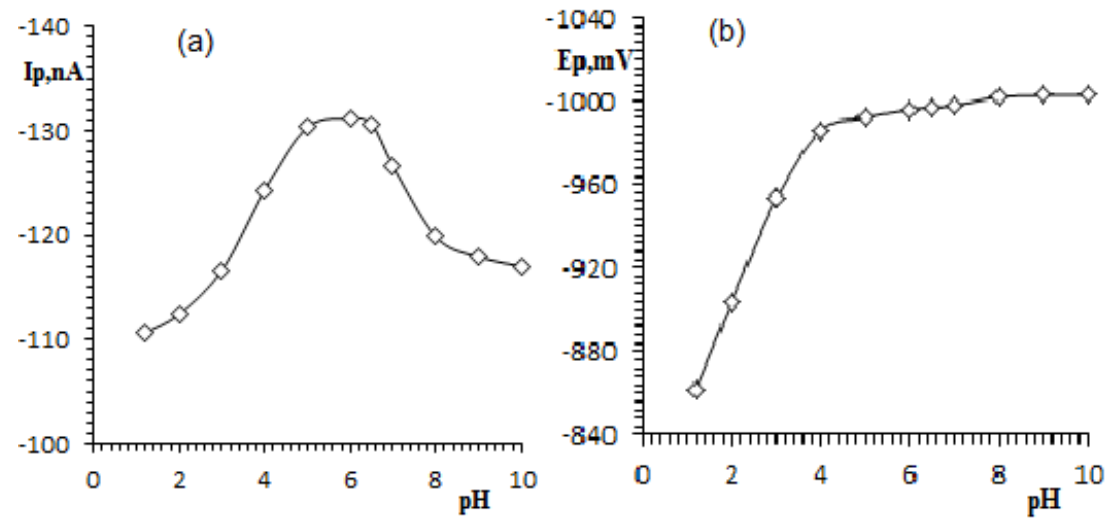

Fig. 2: The effect of pH solution on Ip (a) and Ep (b) of FEN $(2.800 \mu \mathrm{M})$ using DPPA at DME containing $24 \%$ (v/v) acetonitrile with buffer $\left(0.04 \mathrm{M}\right.$ ) lithium perchlorate trihydrate (Purge gas $\mathrm{N}_{2}$, purge time $300 \mathrm{~s}$, sweep rate $5 \mathrm{mV} / \mathrm{s}, \mathrm{U}$. amplitude- $60 \mathrm{mV}$, t. meas. $32 \mathrm{~ms}$, t. pulse $45 \mathrm{~ms}$, t. step $1.6 \mathrm{~s}$, U. step $8 \mathrm{mV}$, temperature $25^{\circ} \pm 5^{\circ} \mathrm{C}$ )

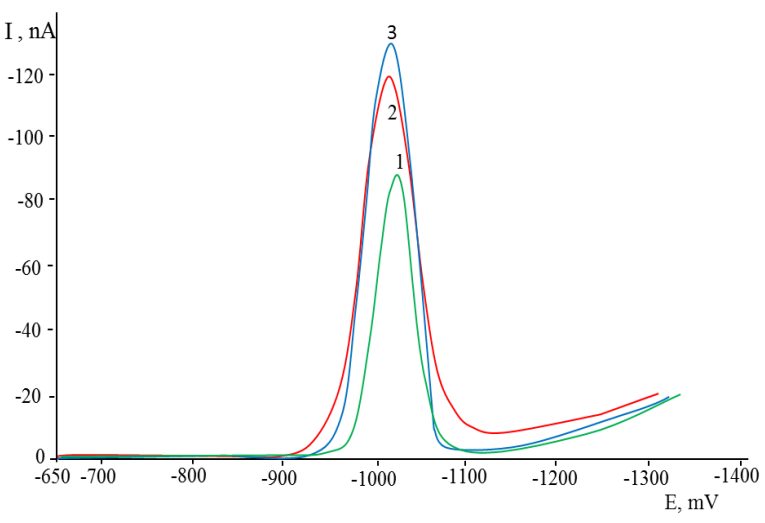

Fig. 3: The effect of organic solvents on polarograms of FEN $(2.800 \mu \mathrm{M})$ using DPPA at DME with buffer (0.04 M) lithium perchlorate trihydrate containing organic solvents: 1-ethanol, 2-methanol, 3-acetonitrile (Purge gas $\mathrm{N}_{2}$, purge time $300 \mathrm{~s}$, sweep rate $5 \mathrm{mV} / \mathrm{s}$, $U$. amplitude- $60 \mathrm{mV}$, t. meas. $32 \mathrm{~ms}$, t. pulse $45 \mathrm{~ms}$, t. step $1.6 \mathrm{~s}$, U. step $8 \mathrm{mV}$, temperature $25^{\circ} \pm 5^{\circ} \mathrm{C}$ )

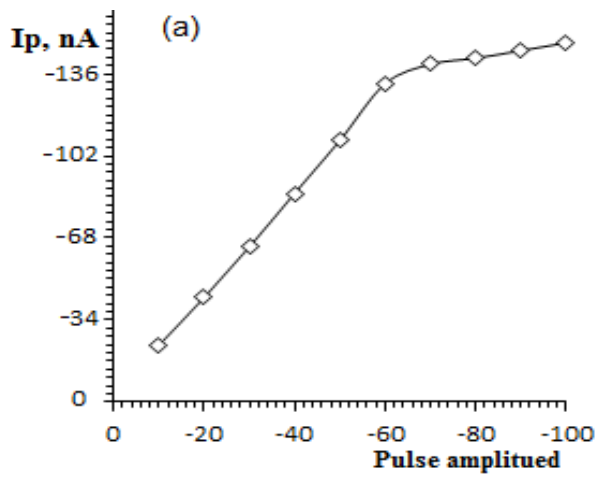

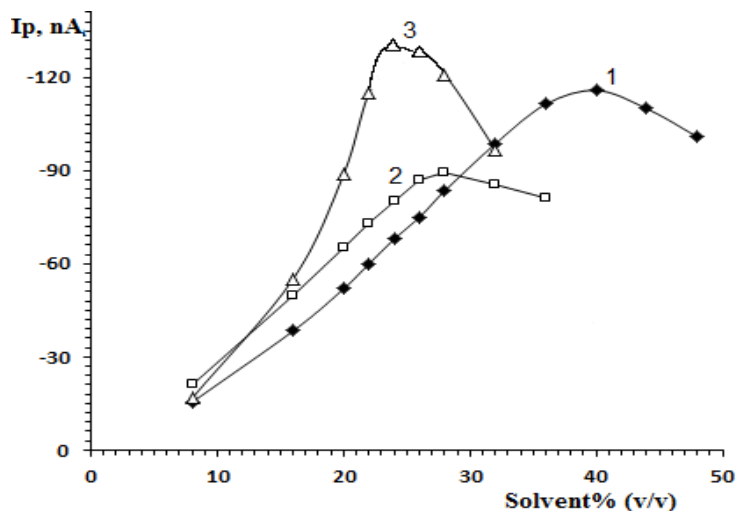

Fig. 4: The effect of organic solvents on Ip of FEN $(2.800 \mu \mathrm{M})$ using DPPA at DME with buffer $(0.04 \mathrm{M})$ lithium perchlorate trihydrate containing organic solvents: 1-methanol, 2-ethanol, 3 -acetonitrile (Purge gas $\mathrm{N}_{2}$, purge time $300 \mathrm{~s}$, sweep rate 5 $\mathrm{mV} / \mathrm{s}$, U. amplitude- $60 \mathrm{mV}$, t. means. $32 \mathrm{~ms}$, t. pulse $45 \mathrm{~ms}$, t. step $1.6 \mathrm{~s}$, U. step $8 \mathrm{mV}$, temperature $25^{\circ} \pm 5^{\circ} \mathrm{C}$ )

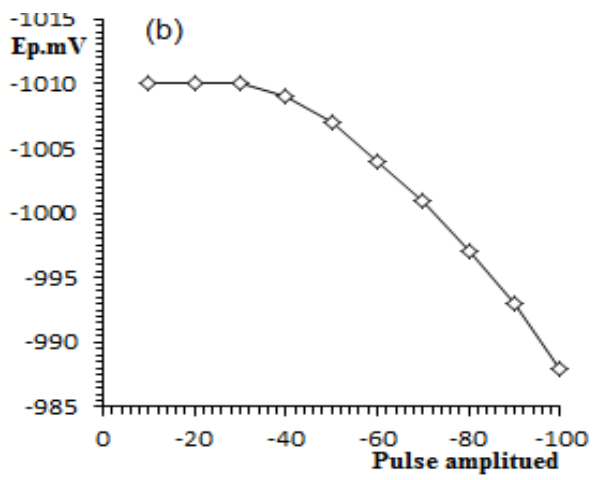

Fig. 5: The effect of negative pulse amplitude ( $\mathrm{U}$ ampl.) on Ip and Ep of FEN $(2.800 \mu \mathrm{M})$ using DPPA at DME (Purge gas $\mathrm{N}_{2}$, purge time $300 \mathrm{~s}$, sweep rate $5 \mathrm{mV} / \mathrm{s}$, U. amplitude- $60 \mathrm{mV}$, t. meas. $32 \mathrm{~ms}$, t. pulse $45 \mathrm{~ms}$, t. step $1.6 \mathrm{~s}$, U. step $8 \mathrm{mV}$, temperature $25^{\circ} \pm 5^{\circ} \mathrm{C}$ )

\section{The effect of initial and final potential}

The effect of initial and final potential on the $\mathrm{I}_{\mathrm{p}}$ and Ep was studied. It was found that better initial potential was- $650 \mathrm{mV}$ and better final potential was- $1400 \mathrm{mV}$.

\section{The effect of temperature and time}

The effect of temperature and time on the electrochemical reaction of FEN was studied at different values $\left(15-35{ }^{\circ} \mathrm{C}, 5-60 \mathrm{~min}\right)$ by continuous monitoring of the $\mathrm{I}_{\mathrm{p}}$. It was found that the value of $\mathrm{I}_{\mathrm{p}}$ was not affected by a temperature between 20 to $30^{\circ} \mathrm{C}$ (the temperature $25 \pm 5{ }^{\circ} \mathrm{C}$ was used). The effect of waiting time was determined at ambient laboratory temperature $\left(25 \pm 5{ }^{\circ} \mathrm{C}\right)$. It was found that the value of $I_{p}$ was not affected by the time between 5 to $60 \mathrm{~min}$.

The effect of time pulse (t. pulse)

The effect of time pulse $(35,40,45,50,55,60,65,70,75,80,85,90$, 95 and $100 \mathrm{~ms}$ ) on polarograms was as the follows: $I_{p}$ decreases 
with increasing time pulse, and $\mathrm{E}_{\mathrm{p}}$ has become latency positive value increasingly ( -1015 to-991 $\mathrm{mV}$ ) with increasing t. pulse. The peak was more symmetrical when the t. pulse value of $45 \mathrm{~ms}$.

\section{The effect of time interval for voltage step (t. step)}

$\mathrm{I}_{\mathrm{p}}$ linearly increases with increasing t. step $(0.2,0.3,0.4,0.5,0.6,0.7$, $0.8,0.9,1.0,1.2,1.4,1.5,1.6,1.8,2.0,2.2$ and $2.5 \mathrm{~s})$, while $\mathrm{E}_{\mathrm{p}}$ has become increasingly latency positive value $(-1004$ to-990 $\mathrm{mV})$ with increasing t. step. The value of the preferred t. step was $1.6 \mathrm{~s}$.

\section{The effect of measurement time (t. meas.)}

$I_{p}$ increases with increasing t. meas. $(4,8,12,16,20,24,28$ and 32 $\mathrm{ms})$, while $E_{p}$ remains quasi-static. The value of the preferred $t$. meas. was $32 \mathrm{~ms}$. The optimum parameters established for determination of FEN using DPPA at DME are showed in table 1.

\section{Calibration curves}

Calibration curves for the determination of fenofibrate using differential pulse polarographic analysis at dropping mercury electrode with negative amplitude in lithium perchlorate trihydrate $(0.04 \mathrm{M})$ buffer at $\mathrm{pH} 6.0$ containing $24 \%(\mathrm{v} / \mathrm{v})$ acetonitrile were applied. One reduction peak was observed in the range-994 to-1025 $\mathrm{mV}\left(\mathrm{E}_{\mathrm{p}}\right)$. The peak current $\left(\mathrm{I}_{\mathrm{p}}\right)$ was proportional to the concentration of FEN over the ranges $0.0361-3.608 \mu \mathrm{g} / \mathrm{ml}(0.100-10.000 \mu \mathrm{mol} / \mathrm{l})$, while the ranges were $0.145-4.96 \mu \mathrm{g} / \mathrm{ml}$ and $0.5-2.5 \mu \mathrm{g} / \mathrm{ml}$ by using optimized conditions of SWV [3] and DPP [5]. The polarograms in the optimum conditions using DPPA at DME of FEN at different concentrations are showed in fig. 6 . The regression equation and correlation coefficient $\left(R^{2}\right)$ were as the follows: $y=-128.72 x-0.6153$, $R^{2}=0.9994$; where $y: I_{p}, n A\left(I_{p}=I_{p, t o t a l}-I_{\text {elect.; }}\right.$ where $I_{\text {elect. }}$ is electrolyte current at $E_{p}$ ) and $x: C_{F E N}, \mu g / m l$, see fig. 7.

\section{Analytical results}

Determination of FEN using DPPA at DME in the optimum conditions using analytical curves, $\mathrm{I}_{\mathrm{p}}=\mathrm{f}\left(\mathrm{C}_{\mathrm{FeN}}\right)$, showed that the accuracy was ready over the ranges of FEN concentration between $0.0361-3.608 \mu \mathrm{g} / \mathrm{ml}$. The relative standard deviation (RSD) was not more than $2.1 \%$. Limit of detection (LOD) and limit of quantitation (LOQ) for the determination of FEN by this method was as the follows: 0.0025 and $0.0076 \mu \mathrm{g} / \mathrm{ml}$, respectively. The results obtained from the developed method have been compared with the official SWV method [3] and good agreement was observed between them (table 2).

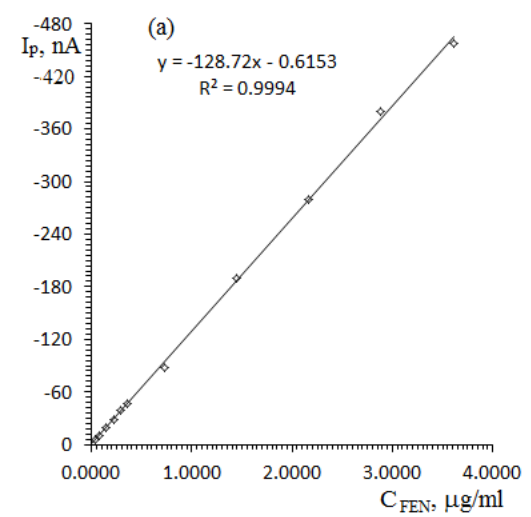

Table 1: The optimum parameters established for determination of FEN using DPPA at MDE

\begin{tabular}{ll}
\hline Parameters & Operating modes \\
\hline Working electrode & Dropping mercury electrode (DME) \\
$\begin{array}{l}\text { Supporting electrolytes } \\
\text { (buffer) }\end{array}$ & 0.04 M lithium perchlorate trihydrate \\
$\mathrm{pH}$ & 6.0 \\
Medium & double distilled deionized water \\
& containing 24\% (v/v) acetonitrile \\
Value of pulse amplitude & $-60 \mathrm{mV}$ \\
Purge gas & Pure N2 \\
Purge time & $300 \mathrm{~s}$ \\
Initial potential & $-650 \mathrm{mV}$ \\
Final potential & $-1400 \mathrm{mV}$ \\
Scan rate & $5 \mathrm{mV} / \mathrm{s}$ \\
U. amplitude & $-60 \mathrm{mV}$ \\
t. meas. & $32 \mathrm{~ms}$ \\
t. pulse & $45 \mathrm{~ms}$ \\
t. step & $1.6 \mathrm{~s}$ \\
Temperature of solution & $25^{\circ} \pm 5^{\circ} \mathrm{C}$ \\
\hline
\end{tabular}
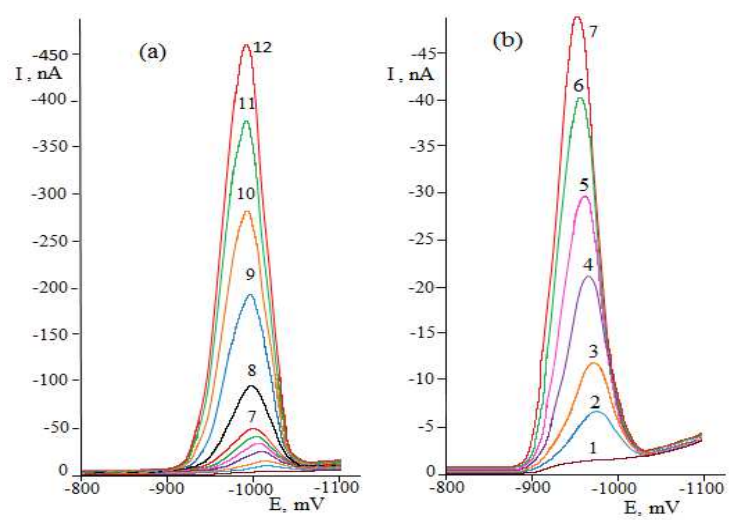

Fig. 6: The polarograms in the optimum conditions using DPPA on DME of FEN in lithium perchlorate trihydrate $(0.04 \mathrm{M})$ buffer at pH 6.0 containing $24 \%(\mathrm{v} / \mathrm{v})$ acetonitrile at concentrations: 1-0; 2-0.0361; 3-0.0722; 4-0.1443; 5-0.2165; 6-0.2887; 7-0.3608; 8$0.7217 ; 9-1.4433 ; 10-2.165 ; 11-2.887$ and $12-3.608 \mu \mathrm{g} / \mathrm{ml}$

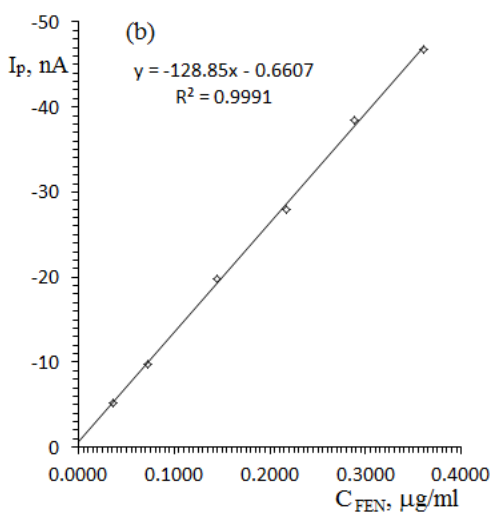

Fig. 7: Calibration curves for the determination of FEN using DPPA on DME in the optimum conditions $\left(I_{p}=I_{p, t o t a l-}-I_{\text {elect. }}\right)$

\section{Method validation}

The developed method for simultaneous estimation of FEN has been validated in accordance with the International Conference on Harmonization guidelines (ICH) [12].

\section{Selectivity}

Selectivity test determines the effect of excipients on the assay result. To determine the selectivity of the method, standard solution of FEN were analyzed. The results of the tests proved that the components other than the drug did not produce any interfere.

\section{Linearity}

Several aliquots of a standard stock solution of FEN were taken in different $25 \mathrm{ml}$ volumetric flasks such that their final concentrations were $0.0361-3.608 \mu \mathrm{g} / \mathrm{ml}$ for FEN using DPPA at DME in lithium perchlorate trihydrate $(0.04 \mathrm{M})$ buffer at $\mathrm{pH} 6.0$ containing $24 \%$ 
(v/v) acetonitrile. Linearity equation obtained was $y=-128.91 x-$ 0.0824 for the mentioned range $\left(\mathrm{R}^{2}=0.9994\right)$.

\section{Precision and accuracy}

The precision and accuracy of proposed method were checked by recovery study by addition of standard drug solution to preanalyzed sample solution at three different concentration levels
$(80 \%, 100 \%$ and $120 \%)$ within the range of linearity for FEN. The basic concentration level of sample solution selected for spiking of the FEN standard solution was $2.165 \mu \mathrm{g} / \mathrm{ml}$. The proposed method was validated statistically and through recovery studies and was successfully applied for the determination of FEN in pure and dosage forms with percent recoveries ranged from $99.8 \%$ to $100.6 \%$, see table 3 .

Table 2: Determination of fenofibrate using differential pulse polarographic analysis on DME with negative amplitude in lithium perchlorate trihydrate $(0.04 \mathrm{M})$ buffer at $\mathrm{pH} 6.0$ containing $24 \%(\mathrm{v} / \mathrm{v})$ acetonitrile

\begin{tabular}{|c|c|c|c|c|c|}
\hline $\begin{array}{l}\text { (Taken) } \\
x_{i}, \mu g / m l\end{array}$ & $\begin{array}{l}\text { (Found) } \\
* \overline{\mathrm{X}} \pm \mathrm{SD}, \mu \mathrm{g} / \mathrm{ml}(\text { mean } \pm \mathrm{SD})\end{array}$ & $\frac{S D}{\sqrt{n}}, \mu \mathrm{g} / \mathrm{ml}$ & $\bar{x} \pm \frac{t . S D}{\sqrt{n}}, \mu \mathbf{g} / \mathbf{m l}$ & RSD \% & $\begin{array}{l}* \overline{\mathrm{X}} \pm \mathrm{SD}, \mu \mathrm{g} / \mathrm{ml} \\
\text { Using SWV [3] }\end{array}$ \\
\hline 0.0361 & $0.0357 \pm 0.00075$ & 0.00034 & $0.0356 \pm 0.00093$ & 2.1 & not determined \\
\hline 0.0722 & $0.0713 \pm 0.0015$ & 0.00067 & $0.0713 \pm 0.0019$ & 2.1 & not determined \\
\hline 0.1443 & $0.1490 \pm 0.0030$ & 0.0013 & $0.1490 \pm 0.0037$ & 2.0 & $0.1392 \pm 0.0054$ \\
\hline 0.2165 & $0.2127 \pm 0.0043$ & 0.0019 & $0.2127 \pm 0.0053$ & 2.0 & $0.2157 \pm 0.0056$ \\
\hline 0.2887 & $0.2943 \pm 0.0056$ & 0.0025 & $0.2943 \pm 0.0069$ & 1.9 & $0.2890 \pm 0.0058$ \\
\hline 0.3608 & $0.3588 \pm 0.0064$ & 0.0029 & $0.3588 \pm 0.0080$ & 1.8 & $0.3600 \pm 0.0062$ \\
\hline 0.7217 & $0.712 \pm 0.0128$ & 0.0057 & $0.7120 \pm 0.0159$ & 1.8 & $0.723 \pm 0.0120$ \\
\hline 1.4433 & $1.482 \pm 0.0252$ & 0.0113 & $1.4820 \pm 0.0313$ & 1.7 & $1.464 \pm 0.0243$ \\
\hline 2.165 & $2.171 \pm 0.0347$ & 0.0155 & $2.1710 \pm 0.0431$ & 1.6 & $2.168 \pm 0.0335$ \\
\hline 2.887 & $2.948 \pm 0.0442$ & 0.0198 & $2.9480 \pm 0.0549$ & 1.5 & $2.879 \pm 0.0430$ \\
\hline 3.608 & $3.553 \pm 0.0533$ & 0.0238 & $3.5530 \pm 0.0661$ & 1.5 & $3.607 \pm 0.0512$ \\
\hline
\end{tabular}

$* \mathrm{n}=5, \mathrm{t}=2.776$.

Table 3: Results of recovery studies

\begin{tabular}{ll}
\hline Level & \% recovery \\
\hline $80 \%(n=5)$ & 100.2 \\
$100 \%(n=5)$ & 99.8 \\
$120 \%(n=5)$ & 100.6 \\
\hline
\end{tabular}

\section{Repeatability}

The repeatability was evaluated by performing 10 repeat measurements for $2.165 \mu \mathrm{g} / \mathrm{ml}$ of FEN using the studied DPPA at DME in lithium perchlorate trihydrate $(0.04 \mathrm{M})$ buffer at $\mathrm{pH} 6.0$ containing $24 \%(\mathrm{v} / \mathrm{v})$ acetonitrile under the optimum conditions. The found amount of FEN ( $\bar{x}_{ \pm S D}$ ) was $2.171 \pm 0.035 \mu \mathrm{g} / \mathrm{ml}$ and the percentage recovery was found to be $100.3 \pm 1.6$ with RSD of 0.016 . These values indicate that the proposed method has high repeatability for FEN analysis.

\section{Sensitivity (limit of detection [LOD] and limit of quantitation [LOQ])}

The sensitivity of the presented method was evaluated by determining the LOD and LOQ. The values of LOD and LOQ for FEN are 0.0025 and $0.0076 \mu \mathrm{g} / \mathrm{ml}$, respectively.

\section{Robustness}

The robustness of the method adopted is demonstrated by the constancy of the absorbance with the deliberated minor change in the experimental parameters such as the change in the concentration of excipients, buffer $( \pm 10 \%)$, acetonitrile $( \pm 1 \%)$, temperature $\left( \pm 5^{\circ} \mathrm{C}\right)$ and waiting time $(30 \mathrm{~min})$.

\section{Specificity}

The specificity of the method was ascertained by analyzing standard FEN in the presence of excipients. These findings prove that the suggested methods are specific for determination of the investigated drugs without interference from the co-formulated adjuvants.

\section{APPLICATION}

Many applications for the determination of fenofibrate in some Syrian pharmaceutical preparations using differential pulse polarographic analysis on mercury drop electrode with negative amplitude in lithium perchlorate trihydrate $(0.04 \mathrm{M})$ buffer at $\mathrm{pH} 6.0$ containing $24 \%(\mathrm{v} / \mathrm{v})$ acetonitrile according to the optimal conditions were proposed. The amount $(\mathrm{m})$ of FEN in one capsule was calculated from the following relationship: $\mathrm{m}=$ h. $m^{\prime}$, where: $m^{\prime}$ is the amount of FEN in capsule calculated according to the regression equation of calibration curve, $h$ conversion factor is equal to 100 for all studied pharmaceutical formulations. The results of quantitative analysis for FEN in pharmaceutical preparations were summarized in Tables 4 . The proposed method was simple, direct and successfully applied to the determination of FEN in pharmaceuticals without any interference from excipients. Average assay ranged between 99.8 to $104.0 \%$. The results obtained by this method agree well with the contents stated on the labels and were validated by SWV method [3]. Therefore, the presented method can be recommended for routine analysis of fenofibrate in pharmaceutical formulations.

Table 4: Determination of FEN in some Syrian pharmaceutical preparations using DPPA on DME with negative amplitude in lithium perchlorate trihydrate $(0.04 \mathrm{M})$ buffer at $\mathrm{pH} 6.0$ containing $24 \%(\mathrm{v} / \mathrm{v})$ acetonitrile according to the optimal condition

\begin{tabular}{|c|c|c|c|c|c|}
\hline Tablet dosage form & Label claim of FEN, mg/cap. & ${ }^{*}$ mean \pm SD (as FEN), mg/cap. & RSD $\%$ & Assay\% & * (Assay\%), using SWV [3] \\
\hline \multirow[t]{2}{*}{ Lipa } & 100 & $99.8 \pm 1.9$ & 1.9 & 99.8 & 100.0 \\
\hline & 300 & $312.0 \pm 4.5$ & 1.6 & 104.0 & 104.3 \\
\hline Lipozor & 250 & $258.5 \pm 4.4$ & 1.7 & 103.4 & 103.4 \\
\hline
\end{tabular}

* $\mathrm{n}=5$, Assay=(found mean/label claim)x100.

\section{CONCLUSION}

Electrochemical behavior and DPPA of FEN in pure form and in pharmaceutical preparations using DME with negative amplitude in lithium perchlorate trihydrate $(0.04 \mathrm{M})$ buffer at $\mathrm{pH} 6.0$ containing $24 \%(\mathrm{v} / \mathrm{v})$ acetonitrile according to the optimal conditions was applied. One reduction peak was observed. Ip is linear over the range 0.0361-3.608 $\mu \mathrm{g} / \mathrm{ml}$; which makes this method more sensitive 
compared to what is available in the literature. The relative standard deviation did not exceed $2.1 \%$ for the concentration $0.0361 \mu \mathrm{g} / \mathrm{ml}$ of FEN. Regression analysis showed a good correlation coefficient $\left(\mathrm{R}^{2}=\right.$ 0.9994 ) between Ip and concentration over the mentioned range. The proposed method was successfully applied to the direct analysis of FEN in pharmaceutical formulations without any interference from excipients and with adequate accuracy and sensitivity without any pre-separation such as extraction.

\section{CONFLICT OF INTERESTS}

The authors have declared that no conflict of interests exists.

\section{REFERENCES}

1. Martindale: The Extra Pharmacopoeia, the Complete Drug Reference. 32nd Ed. K Porfitt. Ed. Royal Pharmaceutical Society, London, UK; 1999.

2. Neil Maryadele JO. The Merck index: An encyclopedia of chemicals, drugs, and biological. 14 ed; 2006. p. 1743.

3. Yardımcı C, Ozaltın N. Electrochemical studies and square-wave voltammetric determination of fenofibrate in pharmaceutical formulations. Anal Bioanal Chem 2004;378:495-8.

4. Sahoo DK, Sahu PK, Patro CS. New validated isocratic RP-HPLC method for the assay of fenofibrate. Int J Pharm Pharm Sci 2014;6:169-72.

5. Mohamed A Korany, Ismail I Hewala, Karim M Abdel-Hay. Determination of etofibrate, fenofibrate, and atorvastatin in pharmaceutical preparations and plasma using differential pulse polarographic and square wave voltammetric techniques. J AOAC Int 2008;91:1051-8.

6. Suresh Kumar GV, Rajendra Prasad Y. Development and validation of reversed-phase HPLC method for simultaneous estimation of fenofibrate and fenofibrate in tablet dosage form. Int J PharmTech Res 2010;2:2016-21.

7. Rupali H, Ravindra B, Manish K. RP-HPLC method for simultaneous estimation of atorvastatin calcium and fenofibrate in tablet dosage forms. J Pharm Res 2010;3:2400-1.

8. Choudhari VP, Nikalje AP. Simultaneous estimation of atorvastatin, ezetimibe and fenofibrate in pharmaceutical formulation by RP-LC-PDA. Pharm Anal Acta 2010;1:111-5.

9. Krishna RG, Sonali SA, Prashant RR, Sudhir GW. Validated spectrophotometric determination of fenofibrate in the formulation. Der Pharm Sin 2010;1:173-8.

10. Sevda RR, Ravetkar AS, Shirote PJ. UV Spectrophotometric estimation of fenofibrate calcium and fenofibrate in bulk drug and dosage form using simultaneous equation method. Int J ChemTech Res 2011;3:629-35.

11. Dhabale PN, Gharge DS. Simultaneous spectrophotometric estimation of atorvastatin and fenofibrate in bulk drug and dosage form by using simultaneous equation method. Int J ChemTech Res 2010;2:325-8.

12. ICH: Proceedings of the International Conference on Harmonization of Technical Requirement of Registration of Pharmaceuticals for Human Use (ICH Harmonized Tripartite Guidelines); 1996. p. 59.

\section{How to cite this article}

- Abdul Aziz Ramadan, Hasna Mandil, Reham Abu-Saleh. Development and validation of differential pulse polarographic analysis of fenofibrate in pure and pharmaceutical dosage forms using dropping mercury electrode. Int J Pharm Pharm Sci 2016;8(10):284-289. 